\title{
ЕФЕКТИВНІСТЬ ВИКОРИСТАННЯ АДИТИВНИХ ТЕХНОЛОГІЙ ПРИ НАКІСТКОВОМУ ОСТЕОСИНТЕЗІ
}

Сорочан О.М., доц., д.Т.н. sorochanen777@gmail.com

м. Маріуполь, Україна

Московцова О.Д., бакалавр moskovtsova@ukr.net

Кафедра біомедичної інженерії Державний вищий навчальний заклад «Приазовський державний технічний університет

Реферат - Отримання «синтетичних кісток» з біосумісних матеріалів для пачієнтів з урахуванням їх індивідуальних анатомоморфофункціональних особливостей є новим етапом в імплантологї та ортопедії. На даний момент немає аналогічних імплантатів створюваних по індивідуальним особливостям пацієнта, здатних до індукуваня остеосинтезу, щчо володіють контрольованою і повною біодеградацією, продукти якої виводяться природними шляхами, а так само повністю біосумісні, так як матеріал є метаболітом.

Ключові слова - накістковий остеосинтез, адитивна технологія, фіксатор, кістка, точність, специфічність, біотехнічна система, 3 д принтер, модель.

\section{I. ВСТУП}

Лікування захворювань і пошкоджень опорно-рухового апарату представляє до теперішнього часу складну клінічну задачу, оскільки частота ортопедичної i травматологічної патології залишається на практично постійному високому рівні [1-7].

Велика кількість людей щоденно отримує травми опорно-рухової системи, це призводить до втрати працездатності пацієнта. Це може бути як тимчасовим, так і довічним процесом. Процес лікування цих та більш складних переломів кісткового апарату лягає на фіксуючі вироби. Застосовуються імплантуючі фіксуючі пластини, штифти, болти, цвяхи. Ці вироби уніфіковані i, на даний момент, виготовляються 3 біосумісних матеріалів, що обумовлює їх постійна присутність всередині організму пацієнта, навіть після реабілітаційного періоду. Для їх вилучення необхідне проведення ще однієї, додаткової, операції.

Персоніфікована медицина має на увазі використання індувідуальних виробів і методів для підвищення якості життя кожної людини. Виготовлення «під замовлення» елементів i органів людського тіла $€$ одним 3 найголовніших завдань регенеративної медицини майбутнього. Такими виробами можуть бути різні частини скелету, що виготовляються 3 повністю біосумісних i біодеградуючих матеріалів, використання яких в травматології та ортопедії дозволить значним чином розширити показання до оперативного лікування, створити нові реконструктивні технології і підвищити якість лікування $[8,9$, $10]$.

\section{II. МЕТА ДОСЛІДЖЕННЯ}

Метою роботи було відпрацювання техніки адитивного 3D друку прототипів кісткових імплантатів 3 полігідроксіалканатів (ПГА) на підставі даних комп'ютерної томографії.

Були поставлені такі завдання:

1. Об'єднання комплексу програм 3 обробки даних комп'ютерної томографії, комп'ютерного моделювання і перетворення в програмний код 3Д принтера $[11,12]$;

2. Отримання прототипів деяких кісток опорного апарату людини зі стандартних ABS полімерів для друку [13]; 
3. Відпрацювати технологію 3Д друку моделей кісток 3 поліефірних матеріалів медичного призначення [14-16].

4. Провести первинну оцінку біологічних властивостей віддрукованих прототипів з полімерів [17,18].

Отримання «синтетичних кісток» 3 біосумісних i повністю біодеградуючих матеріалів для пацієнтів 3 урахуванням їx індивідуальних анатомоморфофункціональних особливостей є новим етапом в імплантології та ортопедії. На даний момент в світі немає аналогічних імплантатів створюваних по індивідуальним особливостям пацієнта, здатних до індукціонування остеосинтезу, що володіють контрольованою і повною біодеградацією, продукти якої виводяться природними шляхами, а так само повністю біосумісні, так як матеріал $\epsilon$ метаболітом [21-24].

\section{III. НАПРЯМКИ РОЗВИТКУ ТА ВДОСКОНАЛЕННЯ МАТЕРІАЛІВ ТЕХНІЧНИХ ЗАСОБІВ І МЕТОДІВ ДЛЯ СУЧАСНОГО ОСТЕОСИНТЕЗУ}

Першими імплантатами для кісткової фіксації стали небіодеградуючі, металеві вироби. Всі вони поділяються на біоактивні, біотолерантні та біоінертні.

До біоактивних відносяться металеві імплантати 3 покриттям з гідроксиапатиту або трікальційфосфатної кераміки. Таку назву вони отримали, так як на металеву поверхню наносився кальцій, що містить мінерал, який сприяє наростанню кісткової тканини [20].

Біотолерантні імплантати навпаки не мали ніякого покриття. Створювалися вони на основі нержавіючої сталі або хромкобальтового сплаву. У теперішній час практично не використовуються через недовговічність, погану приживлюваність i, як виявилося пізніше, ризик розвитку алергічної реакції [26].

Біоінертні імплантати вирішують проблему будь-якого впливу на організм, тому що представлені інертними для біологічних систем сплавами i покриттями. Виготовляються 3 титану, цирконію, золота, корундової кераміки, скловуглецю і є кращими в технологічності і приживлюваності.

Також матеріали для виготовлення імплантів можна класифікувати на біодеградуючі, що розкладаються в біологічному оточенні, всередині організму, коли продукти розкладання або виводяться 3 організму природними шляхами, або використовуються як «будівельний» матеріал, i небіодеградуючі - вони біоінертні, залишаються всередині органу, чи організму на все життя.

Одним 3 основних завдань тканинної інженерії в області лікування кісткових патологій $\epsilon$ створення штучних композитів, здатних в поєднанні 3 біоактивними молекулами (кістковими морфогенетичними білками, факторами росту i т.д.) індукувати остеогенез. При цьому такі матеріали повинні мати ряд необхідних властивостей кістки. Вони мають:

• По перше, виконувати і підтримувати обсяги дефекту [25];

- По друге, володіти остеоідуктивністю , тобто активно спонукати остеобласти до формування позаклітинного кісткового матриксу та мезенхімальні клітини до диференціювання в остеогенні клітини $[27,28]$;

- По трете, повинні мати хороші показники біосумісності, біодеградації і не викликати у реципієнта запальних реакцій [29, 30].

Сукупність цих властивостей дозволить таким матеріалам паралельно 3 опорною функцією забезпечувати біоінтеграцію, тобто вростання клітин i судин в структури імплантату (остеокондуктивних) i стимулювати утворення кісткової тканини навколо імплантату на значному протязі часу (остеоіндуктівних) [5].

Якість зрощування переломів залежить від того, наскільки точно буде проведена репозиція й ії стабільність - фіксація уламків до повної консолідації кістки, достатності кровопостачання пошкоджених тканин, раннє відновлення опорно-рухової функції [11]. Невиконання навіть одніє 3 цих умов уповільнює процес відновлення, а двох часто веде до формування помилкового суглоба. На рисунку можна побачити рентгенівські знімки 3 утвореним помилковим суглобом [20].

\section{IV. МЕТОДИ ВИГОТОВЛЕННЯ МЕДИЧНИХ ВИРОБІВ ДЛЯ ОСТЕОСИНТЕЗУ}


Виробляти однотипні вироби вигідніше великими партіями. Ідеально підходять для цих цілей методи пресування і лиття. Особливістю таких виробництв $\epsilon$ необхідність конвеєрного виробництва (створення схем конвеєрних стрічок), безперервність (зупинки виробництва можуть нести додаткові витрати для підприємства, що збільшить собівартість виробів), контроль відповідності виробів. Виробництво імплантатів має бути досить дешевим, a клінічне використання при наявності остеоіндуктівних можливостей реально гарантує консолідацію пошкодженої кістки в найкоротші терміни [29].

Один 3 найрозповсюдженіших методів виготовлення медичних виробів для остеосинтезу - це метод пресування. Суть методу полягає у впливі тиском на подрібнені гранули матеріалу. Для надання виробу необхідної форми використовуються пресформи, які витримують тиск в рази більше, ніж необхідно для пресування виробу. Прес-форма може складатися 3 двох і більше частин.

Процес пресування може відбуватися як звичайно, так і супроводжуватися нагріванням, наприклад, для плавлення насипного матеріалу, тим самим забезпечити сплавлення мікрочастинок один з одним [31].

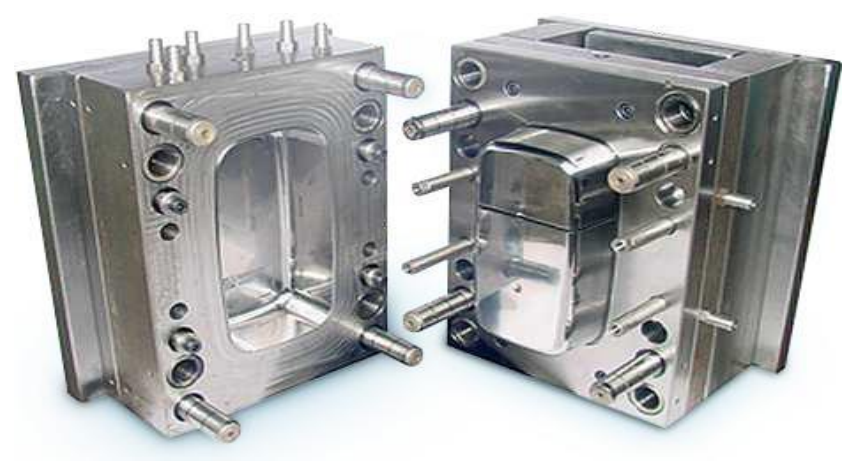

Рис. 1. Пресс-форма.

Другий метод - це метод лиття, який полягає в заповненні спеціальної ємності (форми), яка формує поверхню або частину поверхні виготовляємого виробу, рідким матеріалом (метали і неметали) з подальшим переходом рідкого матеріалу в твердий агрегатний стан і отримання, в результаті, твердої заготовки, близької по конфігурації, розмірам і властивостям до виробу. Цей метод майже не відрізняється для процесів лиття металевих виробів.
Цей метод в свою чергу підрозділяється на два різновиди: лиття під тиском та звичайне лиття [32].

- Лиття під тиском - процес отримання виробів шляхом вприскування розплавленого матеріалу під тиском в ливарні форми 3 подальшим його охолодженням.

Звичайне лиття - процес створення виробиів шляхом заливання розплавленого матеріалу в форму з подальшим його охолодженням. Розплавлений матеріал проникає в форму під дією гравітації.

Лиття під тиском забезпечує меншу усадку, ніж звичайне лиття, тому це є великим плюсом, бо не треба робити розрахунки на відсоток усадки матеріалу.

\section{V. ВИДИ АДИТИВНОГО ПРОТОТИПУВАННЯ}

\section{Види адитивного прототипування поділяються на стереолітографічну технологію, або SLA, лазерне спікання, ламінування та струменеву технологію друку, або FDM [33].}

Принцип стереолітографії грунтується на фотополімері, який знаходиться в рідкій фазі. При просвічуванні цього полімеру ультрафіолетовим промінням певного спектру він застигає, утворюючи надзвичайно щільну і тверду основу. У комплекті з 3D-принтером поставляється спеціальне програмне забезпечення, що розрізає комп'ютерну 3Dмодель на величезну кількість шарів шириною в долі міліметра, що переводить кожен шар в начерк, кожен 3 яких в подальшому буде "надрукований".

Фотополімер заливається тонким шаром в піддон, просвічується по макету шару, застигає, знизу накладається наступний шар, який знову застигає під ультрафіолетовим промінням. Після неодноразового повтору цих дій з'являється готова модель, яка після цього промивається і очищується від облою.

Перевагою SLA друку $є$ :

- Можливість друку форм, порівняно великих розмірів - до 75 см у висоту;

- Найвища якість кінцевої моделі.

3 недоліків можна виділити:

- Велику вартість таких пристроїв;

- Маленьку швидкість прототипування; •Великі габаритні розміри SLA 
принтерів.

Лазерне спікання - ця технологія $€$ найбільш швидкою $\mathrm{i}$ доступною. У ролі заготовчого матеріалу виступає вже не фотополімер, a порошок 3 легкоплавкого пластику або металу.

У 3D-принтері, що працює за таким принципом, лазер вирізує перетин майбутньої деталі на порошку, який розігрівається до температури плавління i потім, остигаючи, спікається з попереднім шаром. Далі процедура повторюється - насипається наступний шар порошку і лазер знову випалює черговий шар.

Перевагами є:

- висока міцність, точність побудови, якісні поверхні;

- $\quad$ немає відходів - невикористаний матеріал можна використати повторно; металу або кераміки: можливість виготовлення

- $\quad$ висока продуктивність.

Недоліками є:

- $\quad$ висока вартість.

Суть технології ламінування в тому, що в машину по черзі заряджаються тонкі аркуші робочого матеріалу, 3 якого лазером або плотером вирізаються шари майбутньої моделі. Після розрізання шари склеюються один 3 одним.

Як матеріал спочатку використовувався спеціальний папір із шаром, що зклеює речовини. Однак таким чином можна також нарізати тонкий пластик, кераміку і навіть металеву фольгу.

Переваги цієї технології $є$ :

- широкий вибір матеріалів;

- точність прототипування.

Недоліки:

- $\quad \epsilon$ ризик розшарування;

- $\quad$ шорсткість поверхні.

Такий метод не варто використовувати при накістковому остеосинтезі.

Ідея струменевої технології друку полягає в тому, що екструзійна голівка вичавлює на охолоджувану платформу-основу розігрітий термопластик (в якості матеріалу може використовуватися практично будь-який термопластик). Він застигає і шари злипаються один з одним, формуючи майбутній об'єкт.

Відносно нова технологія друку живими клітинами в гідрогелі. Технологічно, це переосмислений FDM друк. За винятком того, що в соплі хот-енду в методі FDM полімерний матеріал розігрівається до температури плавління, а тут, навпаки, підтримується температура комфортна для життя клітин. На виході, гідрогель твердне.

\section{VI. МЕТОДИ ОТРИМАННЯ ОБ'СМНИХ ЗНІМКІВ КІСТКОВИХ СТРУКТУР}

Існують два, дуже інформативних методів отримання об'ємних знімків кісткових структур неінвазивним методом: РКТ рентгенівська комп'ютерна томографія, і МРТ магнітно-резонансна томографія [15].

При традиційній КТ отримують серії послідовних однаково просторово розташованих зображень через певну частину тіла, наприклад, черевну порожнину або голову. Принципом дії $\epsilon$ використання рентгенівських променів.

Обов'язкова коротка пауза після кожного зрізу для просування столу 3 пацієнтом в наступне заздалегідь задане положення. Товщина і накладення / міжзрізовий проміжок вибираються заздалегідь. Дані для кожного рівня зберігаються окремо. Коротка пауза між зрізами дає можливість пацієнту, що знаходиться в свідомості, перевести подих i тим самим уникнути грубих дихальних артефактів на зображенні. Інший недолік тонких зрізів - збільшення дози опромінення пацієнта.

В якості основних неінвазивних методів візуалізації хрящових структур i зв'язок в даний час використовується магнітнорезонансна томографія (МРТ). МРТ - спосіб отримання томографічних медичних зображень для дослідження внутрішніх органів i тканин 3 використанням явища ядерного магнітного резонансу. Спосіб заснований на вимірюванні електромагнітного відгуку атомних ядер, найчастіше ядер атомів водню, а саме на порушення їх певним поєднанням електромагнітних хвиль в постійному магнітному полі високої напруженості. За принципом створення знімків апарати МРТ схожі на КТ апарати. Магніт 3 приймачів кружляє, в той час, як пацієнт поступово пересувається по осі обертання. Незважаючи на те, що основні переваги МРТ, до яких відноситься, перш за все, відсутність 
іонізуючого випромінювання, реалізовані в клінічній медицині, рентгенівське випромінювання дозволяє з більшою точністю отримувати об'ємні знімки кісткових структур для отримання моделей вподальшому був обраний метод КТ [35].

Остання стадія процесу створення моделей для адитивного другу - це виокремлення з об'ємних знімків необхідних фрагментів кісток, редагування отриманих моделей і їх слайсінг.

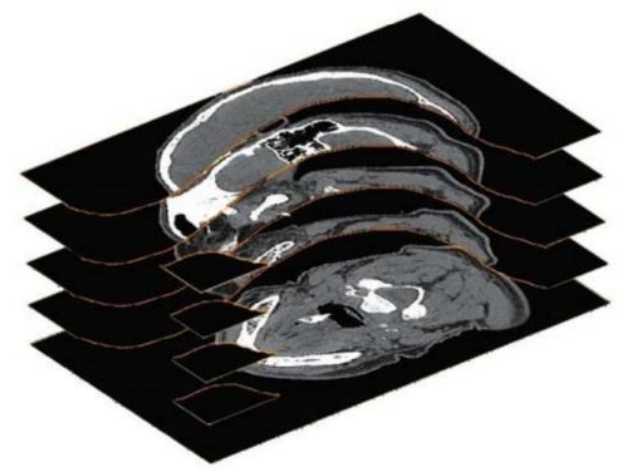

Рис. 2. Послідовність томографічних знімків голови пацієнта

Обробка знімків з КT необхідна, в DICOM файлі міститься інформація про всі структурні елементи різної проникностіі рентгенівського випромінювання. У програмах присутній калібрувальний графік та спеціальні запатентовані алгоритми обробки даних, для коректного виокремлення структур. Далі, отримавши об'ємне зображення кісткового органу, можливо зробити «вирізку» потрібного фрагмента і модель переходить на стадію комп'ютерної обробки в графічних редакторах [15] .

Після внесення необхідних змін в конструкцію майбутнього імплантату, можна переходити до слайсингу. Ключова особливість цього процесу - розшарування об'єкта по вертикальній осі, це адаптує модель під принтер. На даному етапі відбувається налаштування параметрів друку. До таких відносяться: інтенсивність подачі матеріалу, швидкість обдування деталі, швидкість переміщення хот-енду, температури плавління і підігріву підкладки, вид підтримуючого каркасу, заповнюваність i внутрішня структура моделі, й інше.

\section{VII. ВИСНОВОК}

3D прототипування $\epsilon$ дуже перспективною технологією на сьогоднішній день. Вона дозволяє в рази скорочувати час i грошові витрати на виробництво об'ємних моделей, яке вручну не завжди можливо. Розвиток 3D друку відчутно позначається на розвитку різних технологій. Дана робота демонструє, як можна реалізувати новий напрямок об'єднавши регенеративну медицину i 3D друк. Нове десятиліття відкриє нам нові можливості. Якщо говорити про розробки в медицині, вже зараз ми можемо відтворювати структури, які замінять ті чи інші частини організму, наступним етапом стане спрямована тканинна регенерація. На даний момент $\epsilon$ прототип 3 ABS i PLA пластиків власної екструзії, надрукований по томографії знімку реальну людину. На базі цих відпрацьованих моделей так само надруковані зразки з ПГА, що проходять на даний момент лабораторні дослідження [34].

Даний метод ідеально підходить для виготовлення «штучних», індивідуальних конструкцій і в той же час, він менш підходить для виготовлення однотипних деталей у великих обсягах. Якість друку залежить безпосередньо від комплексу факторів: швидкості друку і охолодження матеріалів, температури екструдера i платформи, достатньої вентиляції в області друку, а також від індивідуальних особливостей матеріалу друку і самої моделі.

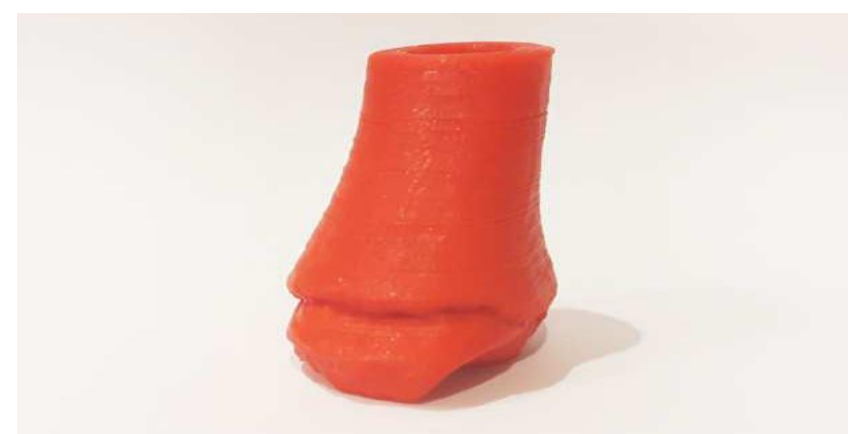

Рис. 3. Прототип імплантату нижньої частині правої великої гомілкової кістки людини

\section{ПЕРЕЛІК ПОСИЛАНЬ}

1. Н. Л. Анкин, Л. Н. Анкин, Н. С. Шидловский, Н. М. Сатышев Экспериментально-биомеханические испытания накостного остеосинтеза при переломах диафиза большеберцовой кости // Вісник ортопедії, травматології та протезування. - 2011. - № 1. - С. 68-75.

2. М. Е. Белов, А. Ю. Азархов, Т. В. Пастухова, Е. Н. Сорочан, В. В. Паладюк, А. Г. Шайко-Шайковский Способ 
бесконтактной дистанционной диагностики воспалительных процессов и физиологических расстройств организма путём оценки теплового излучения // East European Scientific Jounal Wschodnioeuropejskie Czasopismo Naukowe. - 2016. - Vol. 1, № $3(7)$. - S. 100-105.

3. Билинский, П. И. Сравнительный теоретический анализ биомеханических аспектов остеосинтеза при поперечних переломах большеберцовой кости контактными и малоконтактными пластинами / П. И. Билинский, В. И. Чаплинский, Е. А. Андрейчан // Травма. - 2013. - Т. 14, № 2. C. 63-72.

4. Волков, А. В. К вопросу о безопасности остеопластических материалов / А. В. Волков // Вестник травматологии и ортопедии им. Н. Н. Приорова. -2015 . - № 1 . - C. 46-50.

5. И. Л. Головаха [и др.] Оценка напряжений и деформаций системы «кость-фиксатор» при накостном остеосинтезе переломов наружной лодыжки // Ортопедия травматология и протезирование. - 2014. -№ 4 (597). - С. 14 20.

6. Шайко-Шайковський О. Г. [та ін.]. Пат. 2602 Україна, МПК А 61 В 17/56 (2006.01). Пристрій для оцінки міцності гвинтових з`єднань при остеосинтезі - № 2004010379; заявл. 19.01.04; опубл. 15.06.04, Бюл. № 6.

7. Шайко-Шайковський О. Г. [та ін.]. Пат. 29923 Україна, МПК А 61 В 17/56 (2006.01). Пристрій для оцінки міцності гвинтованих з`єднань при остеосинтезі - № u200714108; заявл. 17.12.2007; опубл. 25.01.2008, Бюл. № 2 .

8. Шайко-Шайковський О. Г. [та ін.]. Пат. 2601 Україна, МПК А 61 В 17/56 (2006.01). Пристрій для остеосинтезу 3 хвилеподібним демпфером - № 2004010378; заявл. 19.01.04; опубл. 15.06.04, Бюл. № 6.

9. Шайко-Шайковський О. Г. [та ін.]. Пат. 2604 Україна, МПК А 61 В 17/56. Пристрій для остеосинтезу 3 багатоплощинною фіксацією / - № 2004010381; заявл. 19.01.2004; опубл. 15.06.2004, Бюл. № 6.

10. О. Г. Дудко, А. Т. Зінченко, І. С. Олексюк, О. М. Сорочан, M. Є. Білов, О. Г. Шайко-Шайковський Порівняльний біомеханічний аналіз накісткових фіксаторів для остеосинтезу переломів довгих кісток // XVII з'їзд ортопедів-травматологів України (Київ, 5-7 жовтня 2016 р.) : зб. наук. праць. - Київ, 2016. - С. 240.

11. А. В. Калашніков [та ін.] Порівняльний аналіз ефективності лікування діафізарних переломів стегнової та великогомілкової кістки при різних видах остеосинтезу // Вісник ортопедії, травматології та протезування. - 2013. - № 1 . - C. 17-22.

12. Калашніков, А. В. Порівняльна характеристика ефективності оперативного лікування хворих із черезвертлюговимим переломами стегнової кістки 3 використанням різних металевих фіксаторів / А. В. Калашніков, В. Д. Малик // Вісник ортопедії, травматології та протезування. - 2016. - № 1. - С. 62-68.

13. С. В. Кирилюк [и др.] Биомеханическое обоснование и использование математического моделирования в повышении надёжности и качества остеосинтеза // Надёжность и качество : тр. Междунар. симпозиума (Пенза, 14 февр. 2017 г.). - Пенза, 2007. - С. 142.

14. Лазарев, I. А. Напружено-деформований стан проксимального відділу стегнової кістки 3 наявністю порожнистого дефекта / I. А. Лазарев [та ін.] // Травма. - 2015. - T. 16, № 3. - С. 62-71.

15. А. И. Матущак Математическое моделирование и биомеханическое обоснование остеосинтехза переломов проксимальной частилучевой кости при деформации изгиба / А. И. Матущак [и др.] // Надёжность и качество : тр. Междунар. Симпозиума (Пенза, 14 февр. 2017 г.). - Пенза, 2007. - С. 147 148 .

16. О. М. Сорочан, О. Ю. Азархов, І. С. Олексюк, М. С. Білов, О. Г. Шайко-Шайковський Методика проектування та біомеханічної оцінки конструктивних параметрів накісткових фіксаторів для лікування переломів трубчастих кісток // Молодий вчений. - 2016. - № 9. - С. 106-111. - Режим доступу : http ://molodyvcheny.in.ua/files/journal/2016/9/67.pdf

17. А. Г. Шайко-Шайковский, И. С. Олексюк, Е. И. Бурсук, А. Ю. Азархов, Е. Н. Сорочан, Т. В. Пастухова Методика сравнительной биомеханической оценки стабильности остеосинтеза поперечных диафизарных переломов бедренных костей с помощью различных интрамедуллярных и накостных конструкций // Надёжность и качество : тр. Междунар. симпозиума (Пенза, 23-29 мая 2016 г.). - Пенза, 2016. - Т. 2. - С. 269-271.

18. Сорочан О. М., Азархов О. Ю., Шайко-Шайковський О. Г., Олексюк І. С., Білов М. Є., Махрова Є. Г. Пат. 114602 Україна, МПК5 А 61 В 17/58 (2006.01), А 61 В 17/00 (2017.01). Накісткова малоконтактна пластина для остеосинтезу iз підвищеною жорсткістю та зниженою масою / заявник i власник Вищий держ. навч. заклад України «Буковин. Держ. мед. ун-т» МО3 України. - № u201610067; заявл. 03.10.2016; опубл. 10.03.2017, Бюл. № 5 .

19. Сорочан О. М., Азархов О. Ю., Шайко-Шайковський О. Г., Олексюк І. С., Білов М. С., Махрова С. Г. Пат. 114603 Україна, МПК5 А 61 В 17/82 (2006.01). Накісткова малоконтактна пластина для остеосинтезу 3 приливками та дротяним серкляжем / заявник і власник Вищий держ. навч. заклад України «Буковин. Держ. мед. ун-т» МO3 України. - № u201610069; заявл. 03.10.2016; опубл. 10.03.2017, Бюл. № 5.

20. О. Г. Шайко-Шайковський, О. М. Сорочан, О. Ю. Азархов, М. В. Московко Метод накісткового стабільнофункціонального остеосинтезу // Сучасні проблеми радіоелектроніки, телекомунікацій та приладобудування (СПРТП-2017) : матеріали VI Міжнар. науково-техн. конф. (Вінниця, 28-30 вересня 2017 р.). - Вінниця, 2017. - С. 118-119. 21. А Г. Шайко-Шайковский, Е. Н. Сорочан, М. Е. Белов, И. С. Олексюк, Д. К. Леник Методика компьютерной оптимизации размещения фиксирующих элементов на корпусе 8-ми винтовой накостной пластины при поперечных диафизарных переломах длинных костей опорнодвигательного аппарата // Надежность и качество : тр. Междунар. симпозиума (Пенза, 22-31 мая 2017 г.). - Пенза, 2017. - T. 2. - С. 346-348.

22. Сорочан, О. М. Розрахункові шляхи оцінки проектної міцності накісткових конструкцій / О. М. Сорочан, О. Г. Шайко-Шайковський // Университетская наука - 2017 : Междунар. научно-техн. конф. (Мариуполь, 18-19 мая 2017 г.) : тез. докл. : в 3 т. / ГВУЗ «ПГТУ». - Мариуполь, 2017. - Т. 2. - С. 81-82. - Режим доступа: http://eir.pstu.edu/handle/123456789/14270

23. А Г. Шайко-Шайковский, Е. Н. Сорочан, М. Е. Белов, А. Т. Богорош, И. С. Олексюк Методика компьютерной оптимизации размещения фиксирующих элементов на корпусе накостной пластины при поперечных диафизарных переломах // Наука и образование : сб. тр. Х Междунар. науч. конф. (Рим, 27 апреля - 4 мая 2017 г.) = Science and education : Proceedings of X International conference on science and education (Rome, April 27 - May 42017 у.). - Хмельницкий, 2017. - С. 96-102.

24. Сорочан, Е. Н. Методи та засоби накісткового остеосинтезу опорно-рухового апарату людини / О. М. Сорочан, О. Г. Шайко-Шайковський // Университетская наука - 2017 : Междунар. научно-техн. конф. (Мариуполь, 18-19 мая 2017 г.) : тез. докл. : в 3 т. / ГВУЗ «ПГТУ». - Мариуполь, 2017. - T. 2. - С. 265-266. - Режим доступа: http://eir.pstu.edu/handle/123456789/14456

25. Сорочан, Е. Н. Математическое обоснование конструктивных параметров накостных фиксирующих конструкций для остеосинтеза / Е. Н. Сорочан, А. Ю. Азархов, С. Р. Федорова // Университетская наука - 2016 : в 4 т. : тез. докл. междунар. научно-техн. конф. (Мариуполь, 19-20 мая 2016 г.) / ПГТУ. - Мариуполь, 2016. - Т. 2. - С. 35-36. - Режим доступа : http ://eir.pstu.edu/handle/123456789/9278 
26. Pourbaix M. Electrochemical corrosion of metallic biomaterials // Biomaterials. 1984. Vol. 5, No 3. P. 122-134.

27. Neubauer Т., Wagner M., Hammerbauer С. Система пластин с угловой стабильностью (LCP)-новый АО стандарт накостного остеосинтеза //Вестник травматологии и ортопедии им. НН Приорова. - 2003. - №. 3. - С. 27-35.

28. Ахмедов Б. А., Тихилов Р. М., Атаев А. Р. Остеосинтез пластинами с угловой стабильностью винтов в лечении огнестрельных переломов длинных костей конечностей //Травматология и ортопедия России. - 2007. - №. 2.

29. Гаврюшин С. С. и др. Биомеханическое моделирование индивидуализированных имплантируемых изделий для реконструктивной хирургии.

30. Cuidi Li, Chuan Jiang, Yuan Deng, Tao Li, Ning Li, Mingzheng Peng, Jinwu Wang. RhBMP2 loaded 3Dprinted mesoporous silica/calcium phosphate cement porous scaffolds with enhanced vascularization and osteogenesis properties. Scientific reports. Received 2016 Oct 12; Accepted 2016 Dec 16.

31. Anderson A. J., Dawes E. A. Occurrence, metabolism, metabolic role, and industrial uses of bacterial polyhydroxyalkanoates //Microbiological reviews. - 1990. - T. 54. - №. 4. - C. 450-472.

32. Rai R. et al. Poly-3-hydroxyoctanoate P (3HO), a medium chain length polyhydroxyalkanoate homopolymer from Pseudomonas mendocina //Biomacromolecules. - 2011. - T. 12. №. 6. - C. 2126-2136.

33. Brigham C. J., Sinskey A. J. Applications of polyhydroxyalkanoates in the medical industry //International Journal of Biotechnology for Wellness Industries. - 2012. - T. 1. №. 1. - C. 52-60.

34. Rai R. et al. Poly-3-hydroxyoctanoate P (3HO), a medium chain length polyhydroxyalkanoate homopolymer from Pseudomonas mendocina //Biomacromolecules. - 2011. - T. 12. №. 6. - C. 2126-2136.

35. Brigham C. J., Sinskey A. J. Applications of polyhydroxyalkanoates in the medical industry //International Journal of Biotechnology for Wellness Industries. - 2012. - T. 1. №. 1. - C. 52-60. 


\title{
ЭФФЕКТИВНОСТЬ ИСПОЛЬЗОВАНИЯ АДИТИВНЫХ ТЕХНОЛОГИЙ ПРИ НАКОСТНОМ ОСТЕОСИНТЕЗЕ
}

Сорочан Е.Н., доц., д.т.н. sorochanen777@gmail.com

г. Мариуполь , Украина

Московцова А.Д., бакалавр

moskovtsova@gmail.com

Кафедра биомедицинской инженерии

Высшее учебное заведение

«Приазовский государственный технический университет»

Реферат - Получение «синтетических костей» из биосовместимых и полностью биодеградируемых материалов для пациентов с учетом их индивидуальных анатомо-морфофункциональных особенностей является новым этапом в имплантологии $и$ ортопедии. На данный момент в мире нет аналогичных имплантатов создаваемых по индивидуальным особенностям пачиента, способных к индуцированию остеосинтеза, обладающих контролируемой и полной биодеградацией, продукты которой выводятся естественными путями, а так же полностью биосовместимы, так как материал является метаболитом

Ключевые слова - накостный остеосинтез, аддитивная технология, фиксатор, кость, точность, специфичность, биотехническая система, $3 d$ принтер, модель.

\section{EFFICIENCY OF THE USE OF ADDITIVE TECHNOLOGIES IN NEXT OSTEOSYNTHESIS}

Сорочан Е.Н., доц., д.т.н. sorochanen777@gmail.com

г. Мариуполь , Украина

Московцова А.Д., бакалавр

moskovtsova@gmail.com

Кафедра биомедицинской инженерии

Высшее учебное заведение

«Приазовский государственный технический университет»

\begin{abstract}
Getting a "synthetic bone" of fully biocompatible and biodegradable materials for patients based on their individual anatomical and morphological features is a new stage in implantology and orthopedics. At present, there are no similar implants in the world created according to the individual characteristics of the patient, capable of inducing osteosynthesis, with controlled and complete biodegradation, the products of which are excreted naturally, as well as fully biocompatible, as the material is a metabolite.
\end{abstract}

Keywords - bone osteosynthesis, additive technology, fixator, bone, accuracy, specificity, biotechnical system, 3d printer, model 